

\section{Part D}

\section{Ecological Systems and the Water Resource}

By Luna B. Leopold

CONSERVATION AND WATER MANAGEMENT

GEOLOGICAL SURVEY CIRCULAR 414-D

This volume complete in four parts

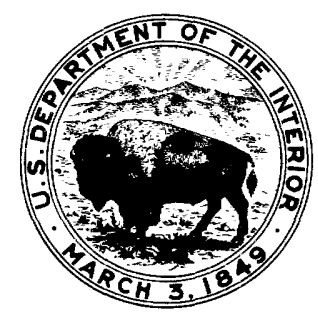


United States Department of the Interior

STEWART L. UDALL, Secretary



Geological Survey

William T. Pecora, Director

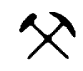

First printing 1960

Second printing 1962

Third printing 1965

Fourth printing 1967

Free on application to the U.S. Geological Survey, Washington, D.C. 20242 


\title{
Ecological Systems and the Water Resource
}

\author{
By Luna B. Leopold
}

Presented before the Sixtb Biennial Wilderness Conference, sponsored by California Academy of Science, San Francisco, Calif., Marcb 20-21, 1959.

In ancient Sparta there were two principal classes of society, the citizen and the helot. The citizen was trained principally to be a warrior. The helot, a serf, was the tiller of the land but could be called to military duty. The history of Herodotus makes it amply clear that making war was the biggest business of the times. Because the Spartans were always marching off to war with someone, they found the landbound position of their city, located as its is in a small central basin nearly surrounded by mountains, somewhat of a disadvantage. When they were under attack, of course, this situation was a favorable one inasmuch as a seaborne enemy had to march inland to come to grips with the Lacedaemonians. The relatively small size of the independent states meant that the Spartans had no direct access through their own lands to the sea.

There is evidence that the Spartans reached an agreement with surrounding states concerning a free corridor. There would be maintained by all the Grecian states of the Peloponnesus an access route stretching essentially from Sparta to Corinth, through which a marching army could have access to a seaport. As a secondary benefit, this no man's land, which in our western lingo might be called a stock driveway, allowed merchants and their caravans to move freely between the flourishing trading port of Corinth and the inland cities to the south and west.

Apparently one portion of the agreement between the states with regard to the use of this access zone was that there should be no permanent agricultural or grazing in the driveway. As a result, through several centuries B.C. during which there was high population density in the Aegean area, one strip of land was exempted from the pressures of grazing, lumbering, and agriculture which characterized most of the rest of the landscape. Today this driveway maintains a forest cover. In contrast, mountainsides nearby with an even larger annual rainfall support hardly a tree.

It is not entirely apparent why subsequent centuries did not see this area denuded. Even with the scanty details known to me it seems clear that the peculiar history of this one area potentially offers us a greater insight into some aspects of forest and land conditions of classical times than extant written records. The several references to sources of timber and cutting of forests contained in the vivid chronicle of Herodotus are valuable, but they lack species identification for the most part. Though rich in human understanding and psychological insight, his history strongly resembles the travel sagas of the Spanish Conquistadors of our Southwest, who had no real eye for "country." Even 
a careful reading of the works of early travelers such as Coronado, Garces, and Espejo, gives no picture of the nature of the country, its vegetation, or its rivers.

To describe a biota there is no substitute for a sample. It is logical to ask what one might want to know which would require the preservation of a sample. Whether such a question is asked at all is a reflection on the stage of intellectual maturity of a civilization. We take for granted that there is social gain in the erection and maintenance of a museum of fine arts, a museum of natural history, or a historical museum. Sooner or later we should be mature enough to extend this concept to include a "museum" consisting of samples of land types as nearly as possible unaffected by man.

There is a growing interest in the preservation of pieces of wilderness. The proponents of the wilderness movement speak about the need for peace and serenity, the rejuvenation of soul as well as body by contact with Nature, and the preservation of scenery for the edification of our grandchildren. Real as these reasons may be, wilderness continues to shrink in size and, in many areas, in quality. Though man cannot live by bread alone, the continual encroachment of civilization into the areas previously untouched or not yet severely modified by man proceeds apace.

It is interesting that this trend continues at the same time that our society is experiencing a sharp awakening to the importance of science for the maintenance and further development of this same society. We seem to recognize the intellectual as well as the economic advantages of exploring the moon and outer space, but we still have corners of our own backyard which are worthy of study.

But they are worthy of study only if natural biological and physical processes are in operation. Some natural processes simply stop operating when the vegetation, the soil, the microbiology, and the hydrologic environment are seriously disturbed. It is to these natural processes in an undisturbed or little disturbed environment, that I wish to call attention.

It is often stated that water tables are falling, that floods are increasing, that the soil resource is deteriorating, and that much of our irreplaceable top soil is slipping seaward. As scientists, it behooves us to take some interest in these questions and, as scientists, to obtain the truest and most objective answers possible. But whether one approaches these problems as a citizen or as a scientist, he immediately faces the fact that answers to these questions must be stated relative to some standard base or datum. What are you going to compare against? Is the standard or datum itself a fluctuating one? Can we agree on a reference point? If each person who tackles such a question uses a different reference for comparison it is quite obvious that answers will all be different.

Let us take the question of falling water tables. We must begin with a mutual understanding of certain hydrologic principles. During rainless periods the flow of water in any small stream is the water which is contributed from ground-water storage. Streamflow in periods between storms represent the overflow of a full ground-water reservoir. When you fill the bathroom basin preparatory to the morning shave, water flows out the drain holes only after the basin has been filled. Such outflow ceases when the water level in the basin drops to the lip of the overflow orifice. So also in a headwater tributary, the stream will stop flowing when the water table drops to the elevation of the streambed nearby.

When an irrigator drills a shallow well near the stream, pumping may reverse the direction of flow, which normally proceeds from the valley deposits toward the stream. When pumping lowers the water level in the valley fill to an elevation below the surface of the nearby stream, 
water from the stream flows into the valley deposits. So the shallow well actually may be yielding water which a very short time ago was merrily flowing down the river. In many semidesert areas, the normal flow is from the river laterally into the valley fill.

Under certain circumstances one can increase the amount of ground water available by pumping the water out of the ground-water reservoir. Such pumping induces infiltration of streamflow into ground-water storage. Pumping of ground water results in local lowering of the water table, because some local lowering is necessary to provide a water-table gradient toward the well. Thus, any use of ground water necessarily implies at least local lowering of the water table. Lowering of the water table is a natural and expected-in fact, necessary-result of pumping. The question is: how much lowering of the water table is permissible, how much more is deleterious, and in what way?

The answer to this is neither simple nor unequivocal. In the first place, the natural daily, seasonal, and secular changes in precipitation cause responsive changes in natural recharge. These changes in rate of replenishment to ground-water storage do not show up immediately, because first, water in the ground usually moves slowly, and second, because available volumes of storage in an aquifer may be very large.

Ground-water levels are constantly changing as natural conditions change. Because of the slow and often attenuated response, changes due to natural causes cannot be computed with any accuracy. This being so, it is often nearly impossible to segregate clearly, changes in water level due to natural causes and those due to man's activities. By man's activities we must obviously include not only pumping, but the effects of land use, changes in ecologic associations, and changes in soil properties in recharge areas.
There are very few areas, except in the special hydrologic environment of some mountainous terrain, where one could follow ground-water changes that are due to natural causes alone. Nearly all environments are not only altered from their original state, but are constantly in the state of still further change. For this reason, only in areas of severe ground-water depletion, primarily in some portions of the Southwestern and Southern States, it is absolutely clear that ground-water withdrawal is greatly exceeding recharge. In those places, continuation of withdrawals at present rates will, in time, lead to exhaustion of the supply, or to pump lifts in excess of the limit of economic feasibility.

It is said by some that a large number of small reservoirs in the headwaters of a drainage basin and the maintenance of forests or grassy cover would increase ground-water recharge and would thus help to solve the problem of overdraft. The evidence for this view is mostly inferential. The ability of a good plant cover to maintain soil tilth and thus infiltration capacity is well known. But infiltration into the soil mantle is not synonymous with infiltration to an aquifer. At each level, soil capacity for moisture, that is field capacity, must be satisfied before water can move to greater depth. Nearly all vegetation draws its moisture from this source. Recognizing that in the hydrologic cycle, on the avera.ge, three fourths of precipitated water is returned to the atmosphere by transpiration and evaporation, we can see that the take of the first claimant, evapotranspiration, is large. Thus it should not be assumed a priori that there will be a net gain of water to surface streams or to aquifer storage by building surface-storage reservoirs. In the only adequate study so far available, it was shown that small reservoirs or stock ponds in the Cheyenne basin, Wyoming, caused a net decrease of streamflow by about 30 percent.

With regard to a heavy cover of vegetation 
increasing ground-water recharge, we may remind ourselves of the well known fact that selective cutting of forest increases water yield under at least some circumstances. The increase of water yield comes from decreasing transpiration by cutting some of the trees.

To summarize, the ecological system-man, land, pump, plow, trees, and climate-experiences much larger variations in ground-water levels than existed in the simpler system of land, trees, and climate. How much larger and how important these variations are is difficult to assess until the situation is flagrantly out of balance. By that time, the trend is nearly irreversible and usually continues until the limit of economic feasibility is reached.

One connotation of the word civilized is awareness of the consequences of one's actions. A civilized nation could and should, in my opinion, afford the maintenance of control areas to study natural variations in physical phenomena, such as ground-water conditions. But the lack of a datum increases greatly the difficulty of making a thorough diagnosis of trends and prospects of ground-water conditions in an area. The lack of such a datum greatly increases the difficulty of appraising the volumes of water available, rates of recharge, of understanding the implications of changes of water table, and in making prognoses of future status of an aquifer. These difficulties partly account for the dearth of adequate appraisals of the water situation in major aquifers in the country.

To take another and perhaps simpler example. Are floods inceasing because of man's activities? Again it is necessary to begin with a common understanding of some of the hydrologic principles involved. For example, a river floods when its water fills the channel and overflows its bank. It is a characteristic feature of river channels that they are constructed by the river large enough to contain only a relatively frequent flow. The bankfull stage in natural channels occurs on the average about once a year, regardless of the size of the river. Flows larger than this must spread over the flood plain. Thus overbank flow may normally be expected on the average as often as once in 2 years.

Overbank flows or floods cause damage because man builds structures, grows crops, or otherwise uses the flood plain. With increase in population and industrialization, the fertile and level flood-plain lands become more intensively used and thus there is a tendency to increase the amount of damageable property potentially within the reach of floods. This is one of the principal reasons for the progressive increase in actual flood damage in the United States up to the passage of the Flood Control Act of 1936. Since the passage of flood-control legislation in 1936, about $31 / 2$ billion dollars have been expended on flood control. As a result, a large amount of damage has been prevented, damage which would have occurred in the absence of the flood-control works. Yet, since 1936, the actual flood damage experienced annually has not decreased, presumably owing to still further encroachment on river flood plains.

But again it is very difficult to determine accurately how much natural or strictly climatic vicissitude accounts for the flood experience on any given river; conversely the hydrologist cannot evaluate the extent to which flood occurrence, in contrast with flood damage, has been altered because of the various direct and indirect influences of man on the environment.

In water yield-that is river flow-the separation of the effects of natural from man-induced changes ought to be easier, because the seasonal and daily fluctuations can be eliminated by expressing water yield as total flow on, say, an annual basis. Yet even these data are difficult to interpret. Many gaging stations in the upper Missouri River basin, for example, show what 
appears to be a rather consistent trend toward lower values of total runoff in the past two or three decades. Yet some individual stations in the same area do not show the trend. Over the United States as a whole there is no distinctive and consistent trend in the records.

Knowing that long-term temperature records, glacier recession, and certain oceanographic and meteorologic elements. indicate a general warming in the northern hemisphere, we might expect an accompanying trend toward aridity and consequent decreasing runoff. But because there is no adequate control which shows such trends uncomplicated by man's activities, clearcut conclusions cannot be reached. There is reason to believe that even our long records of precipitation and temperature have been affected by influences of man on the environment.

When the total period of record of streamflow and other hydrologic elements becomes much longer, let us say twice as long as the presently available 60 -odd years, statistical variance will be better defined. But by that time man's effects and his pressures on the environment will be even more extensive and pronounced. It may well be that it will never be hydrologically or statistically possible to demonstrate what part of the experienced variations in hydrologic conditions is natural and what part is man-induced.

Is it important that we know? Well, much confusion in several fields of activity has resulted from the fact that such questions cannot be clearly answered. For example, graziers maintain that livestock has little to do with the widespread gullying of western valleys, while many others maintain that grazing is the principal cause.

Because no unused area exists which is, in all principal respects, similar to the region under discussion, the factors must be analyzed by roundabout and indirect means. Even now, after years of study by many specialists, there is much we desire to know.

It is clearly shown by geologists that alluvial valleys were channeled by gullies several times in late Pleistocene and geologically Recent time long before man could have had any important effect. It is believed that these gullies eroded the floors of alluvial valleys in response to changes in rainfall-runoff relations associated with climatic variations, but the magnitude of climatic change required to cause the observed results is unknown.

It seems equally clear that the epicycle of erosion which began in the 19th century must have resulted from a combination of climatic and manmade effects. The relative importance of each is still quite unclear. Partly for this reason it is not possible to forcast with any certainty what will be the future of these arroyos. My own studies of this question lead me to believe the gullies in western valleys will not aggrade by deposition in the next several generations, but will gradually tend to stabilize, with their banks rounded and eventually covered with vegetation. I, for one, would be intensely interested in seeing some area typifying the alluvial valley-gully problem protected indefinitely from further use by man or by grazing animal, so that we could observe what erosion or deposition will occur naturally.

For long-term observation of the effect of climatic changes on runoff, the United States Geological Survey is eager to establish and maintain what we would call "benchmark" gaging stations, measuring streamflow from areas which are as free as possible from future man-induced changes. Out of 7,000 gaging stations now maintained in the United States only a few seem to fit the requirement. Even for those, there is no guarantee that the drainage basins will remain free of man's influence indefinitely.

The vast national prugrams of hydrologic measurement are motivated by the same things 
that alter the landscape: water shortage, flood control, and river regulation, to name a few. Virtually none of these programs is devoted first to finding out what changes in the natural regimen these works effect. Much goes into an evaluation of a benefit to cost ratio, but none into an evaluation of man as an agent of ecologic and even of geologic change. The most powerful tools of statistical inference cannot do what benchmark stations can do-unravel man from nature in the records.

Many branches of science would benefit from the study of representative areas maintained as nearly as possible in their original condition. Not only the hydrologist and botanist, but many other specialists might find knowledge of great practical and intellectual interest in such areas. The Belgians have already recognized this need, and the administrative direction of the great national parks in Africa is specifically oriented with this in mind. One of the fathers of the Belgian park system in Africa, $M$. Van Straten, told me that in one of these untouched areas scientists found a spot where the bacillus causing tetanus does not occur. Tetanus is so ubiquitous that to discover a place where it does not exist is indeed rare luck. Study of its natural enemies there might eventually provide a hint as to how the disease might be controlled.

In the field of hydrology, many natural processes can be studied adequately in very small areas. Even the preservation of small basins typical of some of the important ecologic and lithologic types could be of significant value for research purposes.

Science is shooting for the moon. I should be content with much less. If we have learned enough to reach the moon, one would hope that we had learned enough to apply some of this great scientific energy to a few small areas in our own backyard. But we undoubtedly will reach the moon and start to alter its hydrologic economy before we have set aside some representative land museums for science here.

The Spartans left us a sample through inadvertance. Though that sample leaves much to be desired, it is still better than nothing. Presumably we should not have to rely on inadvertence to leave something similar in America, and it is never too late to begin. 